\title{
CONTRIBUTION TO THE OOLOGY OF THE EURASIAN WRYNECK JYNX TORQUILLA
}

\section{Zdravko Dolenec}

\author{
Mokrice 132, HR-49243 Oroslavje, Croatia (e-mail: zdravko.dolenec@biol.pmf.hr)
}

Dolenec, Z.: Contribution to the oology of the Eurasian wryneck Jynx torquilla. Nat. Croat., Vol. 29, No. 1., 123-128, 2020, Zagreb.

In this article I shall present data on the characteristics of the eggs of the Eurasian wryneck, Jynx torquilla, collected in north-western Croatia during the period from 1985 to 2018 using wood nestboxes. Nestboxes were primarily installed for investigation of Passerine bird species (tits Parus sp., tree sparrow Passer montanus and nuthatch Sitta europaea), but approximately one out of a hundred nestboxes per year was occupied by the Eurasian wryneck. In this study, 34 clutches in total were sampled during the first nesting in the study period, after all eggs had been laid. In this paper, oological data of the Eurasian wryneck in the south-eastern Europe area are presented for the first time. It is worth noting, however, that such data are scarce for the whole of Europe. Average number of eggs per clutch was 8.1 (from 6 to 10). Egg length ranged from 17.7 to $21.9 \mathrm{~mm}$ (mean = $20.1 \mathrm{~mm}$ ), egg breadth from 14.2 to $15.9 \mathrm{~mm}$ (mean $=15.1 \mathrm{~mm})$, egg volume from 1856.4 to $2668.9 \mathrm{~mm}^{3}\left(\right.$ mean $\left.=2347.5 \mathrm{~mm}^{3}\right)$ and elongation index from 1.19 to 1.43 (mean $=1.33$ ). Correlation between egg breadth and egg length was significantly positive. Relationship between egg volume and clutch size was not significant.

Key words: Eurasian wryneck, Jynx torquilla, clutch size, egg dimension, NW Croatia

Dolenec, Z.: Doprinos poznavanju obilježja jaja vijoglava Jynx torquilla. Nat. Croat., Vol. 29, No. 1., 123-128, 2020, Zagreb.

U ovome članku prezentirana su osnovna obilježja jaja vijoglava Jynx torquilla na temelju podataka prikupljenih u razdoblju od 1985. do 2018. godine na području sjeverozapadne Hrvatske pomoću umjetnih duplji (škrinjica). Škrinjice su primarno postavljene za istraživanje gniježđenja ptica pjevica (sjenica Parus sp., poljskog vrapca Passer montanus i brgljeza Sitta europaea) ali bi godišnje na otprilike stotinu škrinjica jednu naselio vijoglav. Uzorkovana su ukupno 34 gnijezda tijekom razdoblja prvog gniježđenja, nakon što su snesena sva jaja. U ovome radu prezentirani su po prvi put oološki podaci vijoglava za području jugoistočne Europe, a vrlo je malo podataka i za Europu općenito. U gnijezdu je bilo prosječno 8,1 jaje (od 6 do 10 jaja). Jaja su bila duljine od 17,7 do 21,9 $\mathrm{mm}$ (srednja vrijednost =20,1 $\mathrm{mm}$ ), širine od 14,2 do 15,9 mm (srednja vrijednost $=15,1 \mathrm{~mm}$ ), volumena od 1856,4 do 2668,9 $\mathrm{mm}^{3}$ $\left(\right.$ mean $\left.=2347,5 \mathrm{~mm}^{3}\right)$, a indeks oblika jaja od 1,19 do 1,43 (srednja vrijednost $=1,33$ ). Korelacija između duljine jaja i širine jaja je pozitivno značajna dok između volumena jaja i broja jaja u gnijezdu nije zabilježena signifikantnost.

Ključne riječi: vijoglav, Jynx torquilla, veličina pologa, dimenzije jaja, sjeverozapadna Hrvatska

\section{INTRODUCTION}

In the past few decades, many European habitats have shown a decline in the population sizes of numerous farmland bird species (e.g. HAGEMEIJER \& Blair, 1997; SAnderson et al., 2006; Kuresoo et al., 2011; Battisti \& Dorodo, 2016), and the Eurasian wryneck is one such species. According to Coudrain et al. (2010), the Eurasian wryneck may be limited by breeding cavities and food availability linked with habitat change. Furthermore, many authors have demonstrated the impact of climate change on plants and animals (e.g. Parmesan, 2006), particularly bird species. For instance, changes in 
egg size of the pied flycatcher Ficedula hypoleuca (SкwARsкA et al., 2015) or changes in clutch size in the barn swallow Hirundo rustica (MöLler, 2002) have been reported. Thus, future research into the oology and generally into the breeding biology of birds is very important, especially in relation to habitat change and climate change. Furthermore, a negative relation between clutch size and egg size (egg mass or egg volume) is important for understanding the breeding behaviour; the trade-off between these traits being a crucial factor in life-history theory (SMith \& Fretwell, 1974).

The purpose of this paper is to evaluate egg characteristics of the Eurasian wryneck (Jynx torquilla; alternative common name: European wryneck) in north-western Croatia. This species is an insectivorous non-passerine, non-excavating hole-nesting (occupying an existing tree-hole or nest-box) and migratory bird species (e.g. CRAMP, 1998; Reichlin et al., 2009). The Eurasian wryneck has a body mass of about $35 \mathrm{~g}$ (Weisshaput et al., 2011). According to WINK et al. (2011), like other woodpeckers, this species is a socially monogamous bird species with a very low rate of extra-pair paternity $(0.68 \%)$. The Eurasian wryneck is not an abundant bird species in the farmland area where this research was conducted, and it mainly breeds in small and open forest, parks, traditional orchards and vineyards. The main prey of this small woodpecker is grounddwelling ants (Formicidae) (e.g. Mermond et al., 2009; Benabbas-Sahkl et al., 2015).

\section{MATERIAL AND METHODS}

The study was conducted in the area of the village of Mokrice ( $\left.46^{\circ} 00^{\prime} \mathrm{N}, 15^{\circ} 55^{\prime} \mathrm{E}\right)$, in north-western Croatia, during the period from 1985 to 2018. This research area consists of a mosaic landscape area with small woods, bushes, arable land, traditional orchards, gardens, vineyard, meadows, houses, garages etc., and the elevation is approximately $140 \mathrm{~m}$ above sea level. All the data for this research have been collected by the author, using wood nestboxes. The Eurasian wryneck prefers mainly semi-open landscapes. About 120-140 wooden nestboxes for tits Parus sp., tree sparrow Passer montanus and nuthatch Sitta europaea were installed mainly in isolated small deciduous woods in the farmland area, traditional orchards, and vineyards of the research area, from the mid1980s. The internal dimensions of the nestboxes were $120 \times 120 \times 250 \mathrm{~mm}$ (internal floor area $14400 \mathrm{~mm}^{2}$ ), walls were from 20 to $25 \mathrm{~mm}$ thick, and the front section had a $32 \mathrm{~mm}$ diameter hole drilled $180 \mathrm{~mm}$ from the base. Nestboxes were checked throughout the nesting season. I collected data on clutch size and egg dimensions. Nestboxes are commonly used in various kinds of ornithological research (e.g. Eens et al., 2013; Pотті, et al., 2018; Dolenec, 2019a; Dolenec, 2019b). Length (maximum) and breadth (maximum) of each egg were measured with "Somet" callipers to the nearest $0.01 \mathrm{~mm}$. I calculated egg volume using HOYT"s (1979) equation [V $=\mathrm{L} \times \mathrm{B}^{2} \times 0.51$ (constant)], where $\mathrm{V}$ is egg volume $\left(\mathrm{mm}^{3}\right)$, L is egg length $(\mathrm{mm})$ and B is egg breadth $(\mathrm{mm})$. This is the most commonly used formula for egg volume calculation (e.g. GóRsKI, et al. 2015; DolEnEC, 2016a; BAO et al., 2020). Elongation (egg shape) index (EI) was derived following the standard method of $\mathrm{EI}=$ maximum length/maximum breadth (HoyT, 1976).

\section{RESULTS AND DISCUSION}

In the area of the village of Mokrice, Eurasian wryneck eggs were measured in 34 clutches during the period from 1985 to 2017. The average number of eggs per clutch was $8.1(\mathrm{SD}=1.258$; range $=$ from 6 to 10, Fig. 1). Egg length ranged from 17.7 to 21.9 
$\mathrm{mm}(\mathrm{mean}=20.1 \mathrm{~mm} ; \mathrm{SD}=1.119)$, egg breadth from 14.2 to $15.9 \mathrm{~mm}($ mean $=15.1 \mathrm{~mm}$; $\mathrm{SD}=0.437)$, egg volume from 1856.4 to $2668.9 \mathrm{~mm}^{3}\left(\right.$ mean $=2347.5 \mathrm{~mm}^{3}$; $\left.\mathrm{SD}=219.476\right)$ and elongation index from 1.19 to 1.43 (mean $=1.33$; SD =0.069). Correlation between egg breadth and egg length was significantly positive $(r=0.404, n=34, p=0.018$; Fig. 2). Positive correlation of these parameters is often found in other bird species as well (e.g Zieliñski \& BAÑBURA, 1998; Dolenec, 2011). However, correlation between egg volume and clutch size was not significant $(\mathrm{r}=-0.138, \mathrm{n}=34, \mathrm{P}=0.434)$. According to SMith \& Fretwell (1974), in clutches with a greater number of eggs, the eggs should be smaller. Thus, results of this study do not support the trade-off hypothesis. Similar observations have been recorded in some other bird species (e.g. PolaK, 2010; DoleneC et al., 2005). However, some papers have illustrated a negative relationship between egg size and clutch size (e.g. Saches-Lafuente 2004) and some positive (e.g. Dolenec, 2016b). Clutch size and egg size (volume) values of the Eurasian wryneck in this study are similar to the results collected in other European countries. For instance, according

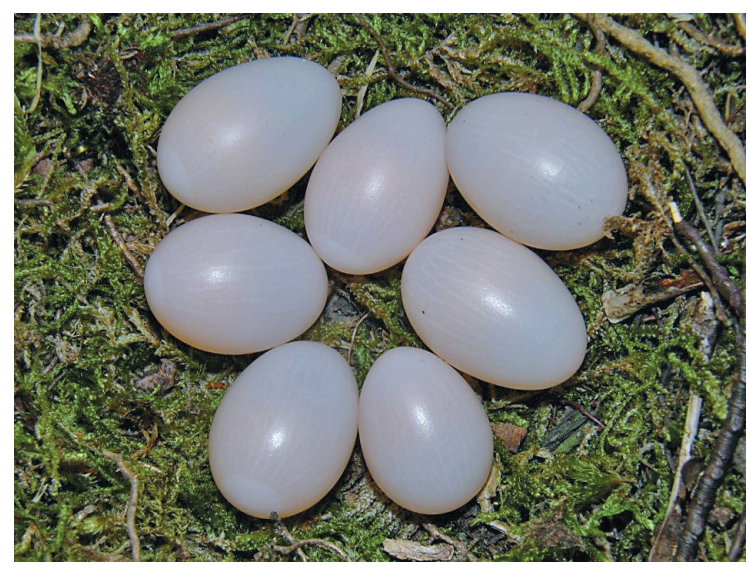

Fig. 1. Clutch of the Eurasian wryneck with seven eggs (Photo: Z. Dolenec).

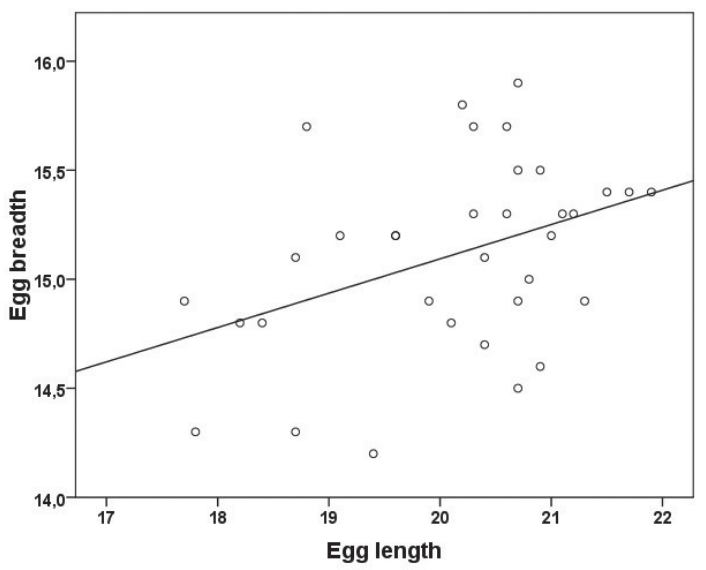

Fig. 2. Relationship between egg length $(\mathrm{mm})$ and egg breadth $(\mathrm{mm})$ of the Eurasian wryneck (NW Croatia). Only first clutches included $(n=34)$. 
to EHREnbold (2004), the average clutch size of the Eurasian wryneck in Switzerland was 8.2 eggs per nest in 2002, and 7.9 eggs per nest in 2004. Furthermore, according to the study of MLíkovský (2006) in the Czech Republic, Eurasian wrynecks' mean egg length was $20.9 \mathrm{~mm}$ and mean egg breadth $15.5 \mathrm{~mm}$.

Understanding the relationship between bird species and habitat degradation is very important for the continuous conservation actions for numerous bird species the populations of which are in decline. In order to preserve Eurasian wryneck populations, conservation strategy should be focused on the maintenance and restoration of semi-open agricultural landscape matrices with loose ground vegetation cover, to provide suitable foraging conditions for this bird species, and with hollow trees or dedicated nestboxes in the surroundings for suitable breeding conditions (Coudrain et al., 2010; Weisshaupt et al., 2011).

Received January 30, 2019

\section{REFERENCES}

BaO, X., ZhaO, W., LiU, F., LI, J. \& MA, D., 2020: Egg investment strategies adopted by a desertic passerine, the Saxaul Sparrow (Passer ammodendri). Avian Research 11, 15 (Open Access).

Battisti, C. \& Dorodo, G., 2016: Mapping bird assemblages in a Mediterranean urban park: Evidence for a shift in dominance towards medium-large body sized species after 26 years. Belg. J. Zool. 146, 81-89.

Benabbas-Sahkl, I., Guerzou, A., SAidi, M. \& Julliard, R., 2015: Trophic Availabilities Impact in Prey-ants on Food Ethology wrineck, Jynx torquilla mauretanica (Linnaeus 1758) (Piciformes: Picidae) in Eastern Plain of Mitidja, Algeria. Egyptian Journal of Biological Pest Control 25, 709-717.

Coudrain, V., Arlettaz, R. \& Schaub, M., 2010: Food or nesting place? Identifying factors limiting Wryneck populations. J. Ornithol. 151, 867-880.

Cramp, S., 1998: Complete Birds of the Western Palaearctic's on CD-ROM. Oxford Univ. Press, Oxford.

Dolenec, Z., 2011: Some breeding traits of the pied wagtail (Motacilla alba) in NW Croatia. Nat. Croat. 20, $209-214$

Dolenec, Z., 2016a: A long-term study of egg dimensions in the Tree Sparrow Passer montanus in relation to climate change. Larus $51,17-24$.

Dolenec, Z., 2016b: Is there a trade-off between clutch size and egg volume in Magpie Pica pica in northwestern Croatia? Larus 51, 33-37.

Dolenec, Z., 2019a: Temporal shift in timing of breeding of European starling (Sturnus vulgaris Linnaeus) population. Current Science 116, 29-30.

Dolenec, Z., 2019b: Interannual variation of the clutch initiation of the great tit (Parus major Linnaeus) in relation to the local air temperature. Current Science 117, 924-926.

Dolenec, Z., Mrakovčić, M. \& Delić, A., 2005: Egg dimensions of the Great Tit (Parus major L.) in Croatia. Pol. J. Ecol. 53, 143-145.

Eens, M., Jaspers, V.L.B., Van Den Sten, E., Bateson, M., Carere, C., Clergeau, P., Costantini, D., Dolenec, Z. Elliott, J.E., Flux, J., Gwinner, H., Halbrook, R.S., Heeb, P., Mazgajski, T.D., Moksnes, A., Polo, V., Soler, J.J., Sinclair, R., Veiga, J.P., Williams, T.D., Covaci, A. \& Pinxten, R., 2013: Can starling eggs be useful as a biomonitoring tool to study organohalogenated contaminants on a worldwide scale? Environment International 51, 141-149.

Ehrenbold, S., 2004: Habitat suitability modelling and components of reproductive success in the Wryneck Jynx torquilla. Diplomarbeit, Zoologisches Institut, Universität Bern, Bern.

Górski, A., NowAkowski, J. J. \& BAŃBUR, J., 2015: Variation in egg-size traits of the European Roller (Coracias garrulus)) in eastern Poland. Ornis Fennica 92, 213-220.

Hagemeijer, E. J. M. \& Blair, M. J., 1997: The EBCC Atlas of European Breeding Birds: Their Distribution and Abundance. T \& A D Poyser, London.

Hoyt, D. F., 1976. The effect of shape on the surface-volume relationships of birds' eggs. Condor 78, 343-349.

Ноут, D. F., 1979: Practical methods of estimating volume and fresh weight of bird eggs. Auk 96, 73-77. 
Kuresoo, A., Pehlak, H. \& Nellis, R., 2011: Population trends of common birds in Estonia in 1983-2010. Estonian Journal of Ecology 60, 88-110.

Mermond, M., Reichlin, T., Arlettaz, R. \& Schaub, M., 2009: The importance of ant-rich habitats for the persistence of the wryneck Jynx torquilla on farmland. Ibis 151, 731-742.

Mцíкоvsки́, J., 2006: Egg size in birds of southern Bohemia: an analysis of Rudolf Prazny's collection. Sylvia 42, 112-116.

Möller, A. P., 2002: North Atlantic Oscillation (NAO) effects of climate on the relative importance of first and second clutches in a migratory passerine bird. J. Animal. Ecol. 71, 201-210

Parmesan, C., 2006: Ecological and evolutionary responses to recent climate change. Annu. Rev. Ecol. Evol. Syst. 37, 637-669.

PolaK, M., 2010: Clutch and egg size variation in the coot Fulica atra breeding on fishponds in eastern Poland - test of the optimal egg dimensions hypothesis. Acta Zoolog. Cracov. 53A, 35-40.

Potti, J., Camacho, C., Canal, D. \& Martinez-Padilla, J., 2018: Long-term occupancy of nest boxes as a measure of territory quality for Pied Flycatchers. J. Field Ornithol. 89, 337-347.

Reichlin, T. S., Schaub, M., Menz, M. H. M., Mermod, M., Portner, P., Arlettaz, R. \& Jenni, L., 2009: Migration patterns of Hoopoe Upupa epops and Wryneck Jynx torquilla: an analysis of European ring recoveries. J. Ornithol. 150, 393-400.

Sanderson, F. J., Donald P. F., Pain, D. J., Burfield. I. J. \& van Bommel, F. P. J., 2006: Long-term population declines in Afro-Palearctic migrant birds. Biol. Conserv. 131, 93-105.

Skwarska, J., Kaliński, A., Wawrzyniak, J., Bańbura, M., Glądalski, M., Markowski, M., Zieliński, P., Bańbura, A. \& BAŃbura, J., 2015: Variation in egg sizes of Pied Flycatchers Ficedula hypoleuca in central Poland: a long-term decreasing trend. Acta Ornithol. 50, 85-95.

Smith, C. C. \& Fretwell, S. D., 1974: The optimal balance between size and number of offspring. Am. Natur. 108, 499-506.

Weisshaupt, N., Arlettaz, R., Reichlin, T. S., Tagmann-Ioset, A. \& Schaub, M., 2011: Habitat selection by foraging Wrynecks Jynx torquilla during the breeding season: identifying the optimal habitat profile. Bird Study 58, 111-119.

Wink, M, Becker, D., Tolkmitt, D., Kmigge, V., Sauer-Gurth, H. \& Staudter, H., 2011: Mating system, paternity and sex allocation in Eurasian Wrynecks (Jynx torquilla). J. Ornithol. 152, 983-989.

Zieliñski, P. \& BañBura, J., 1998: Egg size variation in the Barn Swallow Hirundo rustica. Acta Ornithol. 33, 191-196. 


\section{SAŽETAK}

\section{Zdravko Dolenec}

Svrha ovog članka je dokumentiranje postojećeg stanja nekih ooloških obilježja ptičje vrste vijoglav kao selice i sekundarne dupljašice za koju nema literaturnih nidobioloških podataka kako za hrvatske populacije tako i ostalih područja jugoistočne Europe. Usporedba rezultata ovih ooloških istraživanja s podacima drugih područja Europe sugerira na sličnost broja i dimenzija jaja vijoglava. Odnos između broja jaja u gnijezdu i njihova volumena na području sjeverozapadne Hrvatske ne podržava „hipotezu ustupka“ budući da nema inverzije između spomenutih parametara. Promjene staništa kao i mogući negativni utjecaj klimatskih promjena traži daljnja istraživanja svih životnih ciklusa ove ptice kao jedne od vrsta porodice djetlića (Picidae). 